\title{
ЛИНГВОДИДАКТИЧЕСКИЙ ПОТЕНЦИАЛ ЗООНИМОВ ПРИ ОБУЧЕНИИ РУССКОМУ ЯЗЫКУ
}

\author{
Сухорукова Алиса Александровна \\ студент \\ Научный руководитель: Савелова Любовь Анатольевна \\ д. филол. н., доцент \\ ФГАО ВО «Северный (Арктический) \\ федеральный университет имени М.В. Ломоносова»
}

\begin{abstract}
Аннотация: в статье рассматривается лингводидактический потенциал лексических единиц, представляющих собой наименования животных. Эти наименования отличаются лингвистическим разнообразием - с точки зрения своего состава, происхождения, активности и специфики употребления в современном русском языке. Выдвигается гипотеза о целесообразности использования зоонимов при обучении русскому языку в 6 классе.

Ключевые слова: русский язык, методика обучения русскому языку, результаты обучения, зооним, лексика.
\end{abstract}

\section{LINGUODIDACTIC POTENTIAL OF ZOONYMS IN TEACHING THE RUSSIAN LANGUAGE}

\section{Sukhorukova Alisa Alexandrovna Scientific adviser: Savelova Lyubov Anatolyevna}

\begin{abstract}
: the article considers the linguodidactic potential of lexical units representing animal names. These names are distinguished by linguistic diversity - in terms of their composition, origin, activity and specifics of use in modern Russian. The hypothesis is put forward about the expediency of using zoonyms when teaching Russian in the 6th grade.

Key words: Russian language, methods of teaching the Russian language, learning outcomes, zoonym, vocabulary.

Наименования животных занимают значительное место в словарном составе русского языка. Они часто встречаются в литературных и фольклорных произведениях, а также во фразеологических оборотах, отражающих картину
\end{abstract}


мира, историю народа, особенности его быта и мировоззрения.

Лингвистические характеристики зоонимов позволяют группировать их по разным основаниям. Так, образование наименований самок животных (волчица, волчиха, зайчиха, медведица и др.) и детенышей (волчонок, зайчонок, медвежонок, щзенок, ц̧ыпленок и др.) происходит большей частью по однотипным моделям, соответственно, изучение особенностей этого процесса позволяет расширять знания не только по русскому языку, но и в целом - по окружающему миру (иногда недостаточно знать продуктивные модели, так как некоторые наименования детенышей образуются в результате супплетивизма). Все это говорит о том, что данные единицы обладают лингводидактическим потенциалом, поэтому зоонимы можно использовать при изучении таких разделов, как «Лексика», «Фразеология» и «Словообразование».

Наиболее полно данные разделы изучаются сегодня в 6 классе. Это можно проследить в образовательных программах, рекомендуемых ФГОС, например, под редакцией Т.А. Ладыженской и М.Т. Баранова [1], под редакцией Е.А. Быстровой [2], под редакцией Е. Я. Шмелевой [3] и др.

Однако на каждый из разделов авторы программ не могут выделить большое количество часов, поэтому одной из задач учителя становится максимально эффективно в установленные часы выдать и закрепить материал.

При разработке дидактического материала важно учитывать психологические особенности учащихся. Шестиклассники (дети возраста 11-13 лет) характеризуются резким возрастанием познавательной активности и любознательности, возникновением познавательных интересов. Любознательность носит инфантильный характер, поэтому, на наш взгляд, важно подбирать интересный, соответствующий возрасту, материал. Еще одной особенностью данного возраста является трудность в концентрации, это говорит о том, что подобранный материал должен удерживать внимание учащихся.

Полагаем, что зоонимная лексика позволяет обеспечить выполнение этих требований, так как животные вызывают интерес у детей. Отметим, что успех в обучении шестиклассников во многом зависит от положительных эмоций, поэтому, на наш взгляд, использование данных слов поможет создать благоприятный фон и настроить учеников на работу. Благодаря эмоциональности, которую могут вызвать зоонимы у детей, можно реализовать один из важнейших принципов обучения русскому языку - доступности. 
Важно подчеркнуть, что принцип доступности материала сочетается с принципом научности. Зоонимы позволяют продемонстрировать лингвистические понятия, такие как «многозначное слово», «фразеологизм», «продуктивные суффиксы», «супплетивизм»; проиллюстрировать различные способы словообразования и т. Д., что помогает учителю сформировать достойную базу для последующего обучения.

Таким образом, данная лексика может помочь учителю не только объяснить лингвистические понятия, с которыми школьники до этого не сталкивались, но и закрепить их, благодаря тому, что используется интересный и понятный материал.

На сегодняшний день школьник должен не только усвоить систему знаний, умений и навыков, но и быть разносторонне развитой личностью, обладающей нравственными, социальными и другими ценностями. Предмет «Русский язык» играет в процессе создания такой личности важнейшую роль, что в значительной мере обусловлено его метапредметной функцией, так как без него невозможно приобретение знаний в других образовательных областях.

Русский язык должен формировать и личностные результаты. В первую очередь - это, конечно, ответственное отношение к себе, к своему здоровью и познанию себя. Немаловажным является формирование положительного отношения учащихся к России и Родине, государству и гражданскому обществу; русский язык должен помочь наладить общение с окружающими людьми и выстроить правильные отношения с окружающей средой и природой; воспринимать искусство; подготавливать к семейной жизни и т.д. [5, с.15].

Достижению этих результатов способствует выполнение упражнений. Задания должны соответствовать требованиям Федерального образовательного государственного стандарта к основному общему образованию в таких критериях как: 1) результаты (личностные, предметные, метапредметные) освоения основной образовательной программы; 2) формирование универсальных учебных действий (личностные, познавательные, регулятивные, коммуникативные); 3) формирование компетенций (коммуникативных, лингвистических, культурологических).

Зоонимы обладают дидактическим потенциалом для достижения комплексного результата.

В качестве примера приведем задание № 98 из учебника под редакцией Т.А. Ладыженской и М.Т. Баранова по стихотворению Я. Козловского «Такса»: «Как обыгрывает значение слов такса поэт Я. Козловский? В каких значениях употребляются эти разные слова? Как они называются?» [6, с.55]. Данное 
задание иллюстрирует понятие «омонимы» и развивает умение понимать лексическое значение слова, видеть его зависимость от контекста. Авторы учебника используют зооним такса для иллюстрации того, что связь между лексическими значениями у омонимов отсутствует: 1) «установленная расценка товаров»; 2) «небольшая охотничья собака с длинным туловищем и короткими кривыми ногами» [7].

Упражнение направлено на формирование познавательных и коммуникативных универсальных учебных действий. Первые предполагают поиск и выделение необходимой информации, так как есть возможность воспользоваться толковым словарем, и логическое решение вопроса; вторые ориентированы на осознанное и произвольное построение речевого высказывания в устной и письменной форме, развитие умения с достаточной полнотой и точностью выражать свои мысли в условиях как монологической, так и диалогической речи.

Подобные упражнения развивают следующие компетенции: коммуникативную (учащиеся воспринимают текст, рассуждают, анализируют), лингвистическую (на лексическом уровне, поскольку упражнение закрепляет знания о многозначности и омонимии), культурологическую (работа со словом с учетом обозначаемых реалий).

Зоонимы могут использоваться в качестве дидактического материала при освоении и закреплении различных тем, в частности таких как «Слово основная единица языка», «Лексическое значение слова», «Многозначные слова», «Синонимы», «Исконная и заимствованная лексика», «Профессионализмы», «Диалектные слова», «Фразеологизмы», «Морфологические признаки существительных», «Словообразование существительных» и др. Это должно способствовать формированию соответствующих лингвистических понятий и достижению необходимых результатов обучения: 1) предметные результаты: определение лексического значения слова, совокупности значений многозначного слова, стилистической окраски слова, сферы употребления, подбор синонимов, антонимов; пользование толковыми словарями для извлечения необходимой информации, прежде всего - для определения лексического значения слова, его однозначности или многозначности, разграничение прямого и переносного значения, выявление особенностей употребления; обогащение активного и потенциального словарного запаса, развитие у обучающихся культуры владения родным языком во всей полноте его функциональных возможностей; 2) личностные результаты: знание культуры своего народа, своего края; 
формирование коммуникативной компетентности в общении и сотрудничестве со сверстниками, детьми старшего и младшего возраста, взрослыми в процессе образовательной деятельности; развитие эстетического сознания через освоение художественного наследия народов России и мира, творческой деятельности эстетического характера; 3) метапредметные результаты: умение оценивать правильность выполнения учебной задачи, собственные возможности ее решения; умение строить логическое рассуждение; умение организовывать учебное сотрудничество и совместную деятельность с учителем и сверстниками; работать индивидуально и в группе; формулировать, аргументировать и отстаивать свое мнение [8].

\section{Список литературы}

1. Русский язык. Рабочие программы. Предметная линия учебников Т. А. Ладыженской, М. Т. Баранова, Л. А. Тростенцовой и др. 5-9 классы: пособие для учителей обще образоват. учреждений / М. Т. Баранов, Т. А. Ладыженская, Н. М. Шанский и др. - М. : Просвещение, 2011. - 111 с.

2. Савчук Л. О. Русский язык: рабочая программа: 5-9 классы общеобразовательных организаций / под ред. Е. Я. Шмелевой. - М.: ВентанаГраф, 2017. -154 c.

3. Программа к учебникам «Русский язык. 5-9 классы» для общеобразовательных учреждений / под ред. Е.А. Быстровой, Л.В. Киберевой. - М.: ООО «Русское слово - учебник», 2011. - 32 с.

4. Федоренко Л. П. Принципы обучения русскому языку. - М.: Просвещение, 1973. - 160 с.

5. Примерная основная образовательная программа основного общего образования (одобрена решением федерального учебно-методического объединения по общему образованию, протокол от 08.04.2015 N 1/15) (ред. от 04.02.2020).

6. Русский язык. 6 класс: учеб. для общеобразоват. организаций: в 2 ч. Ч. 1 / М.Т. Бараной, Т.А. Ладыженская, Л.А. Троетенцова и др. - М.: Просвещение, 2015. - 191 с.

7. Ожегов С.И. Толковый словарь русского языка. - М.: Азъ Ltd, 1992. $955 \mathrm{c}$.

8. Федеральный государственный образовательный стандарт основного общего образования. - М.: Просвещение, 2019. - 61 с. 